\section{Katarzyna Roman}

Institute of Russian Studies, University of Warsaw

\section{Tomasz Rawski}

Institute of Sociology,

University of Warsaw

\title{
The Russian Cinema of the Dissolution
}

\begin{abstract}
The paper takes the issue of Russian reckoning cinema after 1989. This current can be defined as comprising the films which try to lay the foundations of a new narrative about the Soviet Union (alternative to the dominant narrative). The authors reflect on the specificity of the filmmakers' critical attitude towards the previous system. The story of the break-up of the Soviet Union turns to be a story of the great catastrophe - the tragedy of the whole society, abandoned by hypocritical intelligentsia and deceived by political elites.
\end{abstract}

Key words: Russian cinema; Russian transition; dissolution; Soviet Union

\section{Introduction}

Ontemporary Russian cinema is not capable of overcoming a sharp dichotomy which, for years, has been determined by two influential film streams. One of them, permeated by the atmosphere of a constant tension between the intellectual and emotional existential experience, has the face of Andrei Tarkovsky and his successors ${ }^{1}$. In opposition to it, there are epic films of the great national(ist) cinema. Therefore, are the Russians interested in anything more than heroic death and sublime poetry? Intuition

\footnotetext{
1 Among them, the creators of the contemporary Russian mainstream existential cinema, such as Andrey Zvyagintsev, Alexander Sokurov, Svetlana Proskurina, seem worth mentioning.

This is an Open Access article distributed under the terms of the Creative Commons Attribution 3.0 PL License (creativecommons.org/licenses/by/3.0/pl/), which permits redistribution, commercial and non-commercial, provided that the article is properly cited. (C) The Author(s), 2014

Publisher: Institute of Slavic Studies, Polish Academy of Sciences

Editor in chief: Jolanta Sujecka

Conception and academic editing of this issue: Maciej Falski
} 
suggests that, in a country where - as Anton Chekhov wrote - Life thrashes a Russian like a thousand-pood stick, artistic thought should tend to be socially critical. The Russian reckoning cinema is almost unseen and, for this reason, particularly worthy of attention.

The policy of glasnost ${ }^{3}$ finally let the gulag literature officially exist. This move could initiate a serious public debate about the uncomfortable past. Alexander Solzhenitsyn, Varlam Shalamov or Yevgenya Ginzburg reported mainly on the great tragedies of the individuals devoid of their subjectivity and dehumanized by the oppressive system. Until today, the biggest literary accusation of the system is Life and Fate by Vasily Grossman. This avalanche of reckoning, however, halted at the sensationalist, halfjournalistic variations on the Soviet period. The film, actually, did not react.

Contemporary Russian cinema still has not made an effort to create an alternative narrative about the Soviet Union. The stream of federal roubles is earmarked by the cinema state fund (Fond kino) mainly for productions of national(ist) cinema ${ }^{4}$. The founding myth of the Soviet Union - The Great Patriotic War (Velikaya Otechestvennaya voyna) - determines Russian politics of memory also today (see de Lazari 2009). President Vladimir Putin annually conducts the great war commemoration in Red Square. The critical approach to the difficult past is consequently marginalized by putting the emphasis exclusively on the heroic themes of the great Pabieda. The Russians are consistent in keeping distant from their own past.

Over the last two decades, only a few artists dared to create the foundations of an alternative narrative of the Soviet Union period. Although the Russians have still not made a canonical film problematizing the Gulag, it seems that one can read a lot about the condition of the Russian society from rarely appearing reflections on the dissolution of the system.

\section{A Slap in the Face of Public Taste ${ }^{5}$}

The convention of realism, so characteristic of the Russian aesthetic code, is not reflected in the cinema of the dissolution. A direct talk about the

\footnotetext{
A. Chekhov, Listy, t. 1-2, trans. N. Gałczyńska, A. Sarachanowa, Kraków 1988.

3 Ros. Гласность - transparency. The first part of the program of perestroika initiated by Mikhail Gorbachev in 1985. The transparency involved the abolition of public censorship and opening discussions about the issues concealed before.

4Just in the last three years the Russians have had an opportunity to see some monumental pictures devoted to World War II: Utomlyonnye solntsem 2 (Burnt by the Sun 2, 2010), Brestskaya krepost (The Brest Fortress, 2010) and Stalingrad (2013); a number of smaller productions with war in the background were made as well.

5 The title of the literary manifesto produced by a group of pre-revolutionary Russian futurists. Here, it is used in association with the avant-garde purport of the discussed films.
} 
complicated past seems to be so hard for Russians that they seek refuge in alternative means of expression. Thus, creating an atmosphere of disaster, they shock with naturalism, plunge into the grotesque and sometimes dissolve into surrealism. Consequently, we move between the destroyed post-industrial places, draggling, rust-eaten trains, omnipresent smell of rotting corpses on the one hand, and a mixture of extreme emotions, a lament interweaved with hysterical laughter, and collective euphoria in the face of tragedy - on the other. Everything is accompanied by narcotic visions, in which the details, sharpened to the maximum, create a mosaic of incompatible elements.

This mixture of aesthetic forms is marked with clear symbols of the dissolution. Numerous busts of Lenin are being devoured by chaotic flames. The military uniforms on dead bodies do not inspire respect any more. The profile of the dead Generalissimo flashes somewhere in the background. The emblems of the Communist Party of the Soviet Union stand on the squares alone, surrounded by the silent emptiness. All this eclecticism has to end up in an asylum. Also this time the Russian authors do not avoid psichushk $a^{6}$, which is, probably, more distinctive to this culture than the well-known matryoshka doll.

In such a way, the Soviet Union breaks down. It has long been just a wellconserved form, devoid of any ideals and even a credible content. What is important, the cinema of the dissolution does not criticize socialism or any other leftist ideas. It rather tries to rethink the beginning of the end, after which Russia joined the turbulent period of transition. The end of Soviet life meant not only the rapid transformation of the economy, but also had its consequences in the symbolic dimension, resulting in the uprooting of the Russian society and depriving it of a relatively stable framework for the collective identity.

\section{Dead souls ${ }^{7}$}

The Russian artists are reluctant to speak about them openly. The situation when Russian society often becomes totally transparent is not surprising, after all, it has not spoken with its own voice for a long time. Devoid of its subjectivity, uprooted and tired, it is unattractive to the spectator. In this

\footnotetext{
6 Ros. психушка, the colloquial name for repressive psychiatry in the Soviet Union. Full name: психиатрическая больница специального типа or психотюрьма. Its victims were: Joseph Brodsky, Vladimir Maximov and many other cultural and political activists. The topos of an asylum often returns in Russian literature (e.g in Anton Chekhov's Palata nr 6 (Hall no 6) or in Victor Pelevin's Chapayev i pustota (Chapayev and the emptiness). The Russian filmmakers also eagerly exploits it, e.g.. Igor Voloshin in $\mathrm{Ya}(\mathrm{Me}, 2009)$.

7 The title of the novel by Nikolai Gogol. Used here with reference to the purport of the work, which raises the issue of the symbolic death of the Russian society.
} 
context, Kira Muratova's Astenicheskyi sindrom (Asthenic Syndrome, 1989), a film appreciated in Berlin and almost unnoticed in the Soviet Union, is even more noteworthy. Muratova courageously takes on this problem.

By portraying single episodes from the everyday life of random people, the director creates the collective hero of the Soviet reality. She takes her metaphor straight from the medical classification of mental disorders. The title itself is a meaningful diagnosis of the situation of the society on the eve of the dissolution, for it means a state of shock or mental exhaustion, resulting from trauma or long-lasting tension. The Russian society, viewed through the lens of Muratova, is on the verge of insanity and constantly oscillates between an explosion of rage and total apathy. Crowd scenes, in which the society takes the form of a sleeping, amorphous mass of people that pours out from all corners of the urban space, are the best evidence of the spectacular failure of the system. The perfect product of Soviet social engineering turns out to be an overwhelmed man that fills out his daily duties mechanically and is incapable of independent functioning. On the other hand, the film evokes the permanent feeling of inner anxiety. Muratova points to the breakdown of social bonds in the traditionally collective society, which leads to mutual aggression. She puts many unexpected acts of physical violence into the main line of the story. Thus, she suggests that they are an integral part of everyday life, just like the ubiquitous scream.

Breathing the atmosphere of constant disinformation and concealment, the society fell into neurosis. Mikhail Belikov perfectly captured this climate in the underrated film Raspad (The Dissolution, 1990), a great metaphor of the system's collapse he inscribed into the story of the Chernobyl disaster. In Belikov's film, people get scraps of news regulated by the Party, instead of getting full information about the world around them. The absurdity becomes monstrous when the reactor explodes. Although the inhabitants of the town are evacuated from the endangered area, they are told that they are leaving on a several-day trip. The society, deliberately misled and completely unaware of the risk, becomes an unnecessary piece of the puzzle that is called the Soviet Union.

The collective wail is the main reaction of broken, solitary people to the death of the system. Muratova tells about it meaningfully in the opening scene of Astenicheskyi sindrom, in which a funeral takes place, with the figure in the coffin ominously resembling Joseph Stalin. By burying the dictator, the director implies that the Soviet Union is falling in the same shape Stalin gave to it. The collective cry for the totalitarian past is the best expression of the helplessness of the passive society.

Today, the problem of the consequences of this process appears in Schastye moe (My Joy, 2010) directed by Sergey Loznica. Loznica criticizes 
the Russian society as it appears at the beginning of the 21th century. The director, endowed with a strong naturalistic verve for aesthetics, walls in a dead body in the foundations of a newly built building. Although Loznica does it without any redundant comments, making the corpse in the foundations the first scene of the film carries a clear message - the decay of the system begins at its very roots. The tragedy of the damaged Russian province, Loznica perfectly displays, is just the result of that process. Furthermore, his vision of the Russian province resembles a dark realm of evil where the demons take on human form, like in Fyodor Dostoyevsky's Demons. There can be no question of social bonds, mutual aid or collective cooperation, the latter so characteristic of the Russian context. The residents of this forgotten land are devoid of compassion, trust and hope. They act for their own benefit, the result of their desperate endeavour to survive. However, in Muratova's films, Russian society still has the strength to cry. In the images of Loznica, it has already fallen into a complete stupor.

\section{Woe from Wit $^{8}$}

Traditionally, the Russian intelligentsia was consistently taking the role of proponent and guardian of the Russian people. However, according to the filmmakers, it did not bear the burden of responsibility at the crucial historical moment. Belikov presents the entire range of characteristic attitudes - from the state-controlled intelligentsia that is entirely dedicated to the system to the intelligentsia which stands up for the society. The nuclear engineer from Raspad or the university professor, portrayed in detail by Alexei Balabanov in Gruz 200 (2007), belong to the first group. They are both political conformists and they both die in the ruins of the great projects they have dedicated their whole lives to. The first one dies in the flames of an erupting reactor and the second, the professor of scientific atheism, decides to accept baptism. The lot of the very few intellectuals from the other end of the spectrum is equally tragic. When the holy Tola from Raspad, a doctor who risks his life to save people from the consequences of the system failure, almost falls upon the political dignitaries, no one wants to hear his desperate accusation.

Half way between these extremes there is Nikolai, a representative of the "torn apart" intelligentsia and the main character of Astenicheskyi sindrom, who cannot cope with a schizophrenic reality. The teacher-writer, on the one hand is a part of the state-controlled intelligentsia that reproduces the system, but on the other, he feels vocation to create art. In this situation, he makes

8 The title of the drama of Alexander Griboyedov. Used here with reference to the purport of the work, which raised issues relating to the beginnings of the rootless intelligentsia as a social class; 
desperate attempts to immerse in the creative process. He unsuccessfully seeks refuge from the human gibberish that attacks him everywhere, the gibberish being a pervasive metaphor of control and censorship. In the reality of hackneyed formulas produced by the propaganda and constantly repeated by the stunned people, the teacher has no chance even for a flash of an unconventional creative thought. He is forced to hide from extreme frustration in a mental shell of passivity. Muratova condemns Nikolai to a narcoleptic disorder and makes him eventually end up in an asylum. In this way she tells the story of the dormant Russian intelligentsia.

A sleepy atmosphere of stagnation prevails also in the flat of Alexander, the acclaimed Kiev journalist from Raspad. His home is a meeting place for the hermetic Ukrainian intelligentsia of the late 1980s, already stripped of its identity, which, originally, defined itself by being devoted to a common cause - work for the emancipation of the people. Belikov exposes the superficiality of the intelligentsia's actions, which alienate it from the society, even if they unite it as a group. Alexander's fellowship feeds on illusions about its own rebellion, being, in fact, absorbed in listening to the music of Vladimir Vysotsky ${ }^{9}$, making unsuccessful shows of erudition and cynical comments on reality. This inert atmosphere forces Alexander, who is still trying to believe in some values, to embark on a continuous struggle. Alexander seems to be a tragic figure, mainly because the only choice he can make is the choice between internal exile and actions that legitimize the system. After all, when he goes along with other volunteers to the radioactive zone, he does it within the convention proposed by the system. The scene when he gets on the plane in the lights of flash lamps and TV cameras, only seals this pact. The Russian intelligentsia as a social class is, in Belikov's film, too weak to take more radical actions. Although it still exists, it remains only a relic. Kira Muratova does not have illusions in this matter - the tragic loneliness touches her Nikolai to the same extent as the whole atomized society.

The Russian intelligentsia implants its helplessness into its descendants. The generation of the breakthrough is doomed to failure. It will be able to speak only twenty years later in the film $Y a(M e, 2009)$, directed by Igor Voloshin, a crushing self-reflection which takes the form of both a personal and collective confession. The lost hero, a member of the young generation, who grew up during the Russian transition, voluntarily allows himself to be locked up in an asylum, just to avoid an army call-up. The asylum is a distinct metaphor of the omnipresent insanity of the system. The only choice one can make is a choice between being a part of an oppressive total institution

\footnotetext{
9 Vladimir Vysotsky was a symbol of rebellion that was tolerated by the authorities; his compositions were the safety-valve for any subversive social moods.
} 
and dying a compulsory death for the callous system. The crushed cultural avant-garde of young Russians drowns in the hell of addiction. The portrait of the perestroika drug generation, which was thrown into the trash bin of history, is meant to be the guilty conscience not only of the cultural elites, but also of the political ones.

\section{How the Steel Was Tempered ${ }^{10}$}

The artists unanimously blame the political verhushka for this tragic situation. Seemingly, there is nothing extraordinary in this accusation. After all, when the time of reckoning comes, the first sting of criticism is usually aimed primarily at the authorities. On Russian ground it is, however, an unprecedented event. In the films of the late 80 s and 90 s, such criticism is expressed primarily on the symbolic level. Only in 2007 Aleksei Balabanov decided to charge the political authorities most uncompromisingly, in the heavy Gruz 200.

Gruz 200 is a code name for the action of transporting back home the bodies of the Russian troops killed in Afghanistan. The film itself is a picturesque metaphor for the beginning of the USSR's disintegration. The attempt to renew the symbolic power of communism, through supporting the Afghan communist regime, turned out to be a spectacular failure of Leonid Brezhnev and his successors. Under the pretext of criticizing the Soviet intervention, the director tries to expose the bare, concrete carcass of the system. Balabanov reveals the superficiality of the system, exposing one of its founding myths. The image of a Soviet soldier as a monumental hero, consistently supported by the authorities, is crushed gradually, together with the successive shipments of Gruz 200. Instead of returning in glory, the soldiers return to their homeland in zinc coffins. Even then, however, there are no gun salutes awaiting them at ceremonial funerals. In the background, the director develops the story of Colonel Mikhail, who is responsible for getting rid of the troublesome loads. He is put by his commanders in a difficult situation and is constantly looking for appropriate spots to place the bodies quietly, thus covering up the growing amount of evidence for the huge system failure.

Balabanov's Afghanistan is just a spark in the fire of criticism, which focuses mainly on the myth of the Great Patriotic War. A disappointed veteran appears in almost every one of the discussed films. In Muratova's Astenicheskyi sindrom, he questions the point of fighting for the country and in Loznica's Schastye moe he takes the form of an insane old officer,

${ }_{10}$ The title of the novel by Nikolai Ostrovsky. Here, the association is with the severity and ruthlessness of the system's foundations. 
still convinced that he is on the battlefield and ritually relaying reports to his imaginary commanders. We have won the war, he says, no enemy could avoid the righteous bullet. The visions of general happiness he was inoculated with, did not, however, coincide with the post-war reality. The children were to laugh and the stars were to shine in the sky. Yet, the cheated old officer with the stick pretending to be a gun, wanders aimlessly along the snow-covered side roads.

Belikov in Raspad draws a parallel between the destructive power of the victory over fascism, which sponsored the myth of the great power of the Soviet Union, and the destructive power of the nuclear explosion in Chernobyl. The symbolic scene of raising the red flag at the top of the ruined reactor indistinguishably resembles the famous photo of Yevgeny Khaldei, where the young Soviet soldier puts the red flag at the top of the destroyed Reichstag ${ }^{11}$. This association is sufficient for a meaningful punch line - only the empty symbol fluttering on the ruins of the great disaster will remain after the passing of the Soviet Union. Unfortunately, it is the society which will bear the brunt of the disaster's aftermath.

The artists, besides, unanimously emphasize the huge gap between the people and the authorities, the gap which relieves the latter of any scruples about using violence. Gruz 200 pointedly illustrates the criminal methods of subduing the "unruly" society. In the film, the prison guards still prefer the Stalinist way of execution; even at the beginning of perestroika. Aleksey, one of the characters, illegitimately taken into custody, gets a shot in the back of the head. The murder takes place in the prison corridor while Aleksey is, allegedly, being led by the prison guards to the visiting room. Constant terror, built on cowardice and treachery is, in the opinion of Balabanov, the main element that defines the political power.

Captain Zhurov, a psychopath in a police uniform, is the personification of the aforementioned power. Relentless and frigid Zhurov consistently tortures his victims. Balabanov makes us see him as a Chekist. The fact that the merciless torturer suffers from impotence, seems not to be accidental, for, in Russian texts, this disorder is usually attributed to members of the security service (see Heller 1974). Zhurov twice rapes the kidnapped daughter of a party dignitary, a metaphor of the unionized Russia. In one scene, he does it with a glass bottle, in the other - he observes how a recidivist, pulled out for this purpose from prison, does it. The direct association with the Chekist leaves no doubts - the methods of the police from the mid80 s do not differ from the mass murders committed by the revolutionary

11 The photograph was taken in May 1945, on the eve of capturing Berlin by the Soviet troops. The photograph was staged and patterned on the picture of raising the United States flag on the island of Iwo Jima in 1915, taken by the American photographer Joe Rosenthal. 
police. Thus, the machinery of terror, created by the political elites, slips out of their control. Justice can reach Zhurov only at the hands of Tonya, the embodiment of pre-revolutionary Mother Russia. In Balabanov's vision, she is the only one, who cares about the traditional values.

\section{The Russian skaz ${ }^{1}$}

The directors of the Russian cinema of the dissolution speak with one voice - the dissolution is a long process, deeply rooted in the past. It is a process that eventually must lead to a terrifying disaster. The three main heroes of the Russian skazka about the collapse invariably are: the society, the intelligentsia and the authorities. The story spun by the Russian filmmakers, however, is not like the traditional folk fairy tale. This time, Ivan Durak, the representative of the people, does not win. The mysterious power of wisdom passed on by an invisible patron does not help him either, whereas the uprooted authorities, who do not believe in the holy icons or fairy tales, leave behind them a steel structure in which the Russians are forced to live until today.

Observing the society, almost buried alive by the authorities, one may think that it will just continue plunging into disaster. However, Belikov and Loznitsa imply that it can unexpectedly cross the impassable border, in a desperate fit of rage. In both films, people raise their hand against the authorities. Raspad just alerts by a dignitary's limousine, being turned over. Schastye moe, a film made twenty years earlier, is a far more dramatic warning. The final scene is the scene of a murder - the two Russian traffic police officers get killed by the main character.

\section{References}

Ferretti Maria (2002). “Расстройство памяти: Россия и сталинизм,” Полит.ру (Nov. 2002): http://polit.ru/article/2002/11/20/474876/ [online Jul. 2013].

Heller Michaił (1974). Świat obozów koncentracyjnych, a literatura sowiecka, transl. M. Kaniowski. Paryż.

De Lazzari Andrzej (2009). Polskie i rosyjskie problemy z rosyjskością. Łódź.

\section{Filmography:}

Astenicheskyi sindrom (The Asthenic Syndrome), director: Kira Muratova; screenplay: Aleksandr Chernykh, Sergiej Popow, Kira Muratova; cast: Siergiej Popow, Pavel Polishchuk, Aleksandra Svenskaya, et. al.; produced in: the Soviet Union; year of production: 1989; length: $153 \mathrm{~min}$.

A form of narrative most characteristic of Russian literature. 
Raspad (The Dissolution), director and screenplay: Mikhail Belikov; cast: Sergey Shakurov, Aleksey Gorbunov, Aleksey Serebryakov, et al.; produced in: the Soviet Union, the United States of America; year of production: 1990; length: $103 \mathrm{~min}$.

Gruz 200 (Gruz 200), director and screenplay: Aleksej Balabanov: cast: Aleksei Poluyan, Aleksey Serebryakov, Agniya Kuznetsova, et. al.; produced in: Russia; year of production: 2007; length: 89 min.

$Y a(\mathrm{Me})$, director and screenplay: Igor Voloshin; cast: Artur Smolyaninov, Andrei Khabarov, Oksana Akinshina, et. al.; produced in: Russia: year of production: 2009; length: $89 \mathrm{~min}$.

Schastye moe (My Joy), director and screenplay: Sergey Loznica; cast: Viktor Nemets, Aleksey Vertkov, Vladimir Golovin, et. al.; produced in: Ukraine, the Netherlands, Germany; year of production: 2010; length: $127 \mathrm{~min}$.

\section{Rosyjskie kino rozpadu}

Tekst podejmuje problematykę rosyjskiego kina rozliczeniowego po 1989 roku słabo widocznego nurtu próbującego stworzyć zręby nowej narracji o Związku Radzieckim, która mogłaby stanowić alternatywę wobec narracji dominującej. Stanowi próbę namysłu nad specyfiką krytyki poprzedniego systemu przeprowadzaną przez twórców tego nurtu. Opowieść o rozpadzie Związku Radzieckiego okazuje się tu opowieścią o wielkiej katastrofie - tragedii całego społeczeństwa, opuszczonego przez obłudną inteligencję i oszukanego przez elity polityczne. 